\title{
RAPID AND MULTIFACETED PRIVATIZATION: EXPERIENCE OF THE CZECH AND SLOVAK REPUBLICS
}

\author{
by Josef Kotrba and Jan Svejnar
}

\section{Introduction}

Like the other formerly communist countries, Czechoslovakia commenced its transformation process from a position of extreme state ownership of the economy. Czechoslovakia was in fact exceptional in that the extent of etatization was greater than in most other socialist economies - only $1.2 \%$ of the labor force, $2 \%$ of all registered assets and a negligible fraction of the nation's GDP belonged to the private sector in 1989. This low share did not change very much in 1990, when official statistics still attributed only $4 \%$ of GDP to the private sector. As can be seen from Table 1, in 1992 the private sector started to grow rapidly in retail trade and construction, mostly as a result of restitutions and small scale privatization. In contrast, industry remained predominantly in state hands throughout the first half of 1993 and it was not until the second half of 1993 that the share of private ownership in industry increased as a result of the massive transfer of shares of enterprises in the large scale privatization program.

Table 1 - SHARE OF PRIVATE SECTOR ON OUTPUT IN THE CZECH REPUBLIC, 1990-mid $1993(\%)$

\begin{tabular}{lcccc}
\hline & 1990 & 1991 & 1992 & $1993^{*}$ \\
\hline GDP & & & & \\
Industrial production & 4.0 & 11.0 & 19.15 & 44.2 \\
Construction & n.a. & n.a. & 14.5 & 17.6 \\
Retail trade & n.a. & n.a. & 46.0 & 60.2 \\
\hline
\end{tabular}

* January to June.

n.a. not available

Source: Czech Statistical Office, CNB.

The issue of privatization attracted considerable attention immediately after the fall of the communist regime in November 1989. It was addressed by the electoral programs of virtually all political parties in the first free elections in post-communist Czechoslovakia in June 1990, and the resulting legislation and practices related to privatization evolved into three main strands. First came the restitution laws which legislated the return of certain types of property to previous owners. Second was the so-called 'small scale privatization', used mostly for privatizing smaller units in public auctions. Last, but in terms of its scale the most important

University of Pittsburg, CERGE at Charles University and Economics Institute of the Academy of Sciences, Prague. 
was the 'large scale privatization', an approach covering large as well as mediumsize firms and involving methods ranging from auctions, tenders and direct sales to the widely publicized voucher method. It also allowed free transfer of property to municipalities, health insurance companies and other publicly beneficial institutions. Across these three strands of privatization ran a free transfer of property to municipalities, which sometimes eventually resulted in a further transfer to private owners.

All of these privatization programs aimed at promoting the emerging private sector but they had different effects. From the financial standpoint the most important program was clearly that of large scale privatization - by 30 June 1993, 597 billion Czechoslovak koruna (Kcs) worth of property was approved for privatization under this program, with Kcs 278 billion of property being distributed via the voucher scheme alone. Moreover, about 6,000 municipalities received free property transfers worth Kcs 350 billion in 1991 and additional property was distributed to municipalities within the large scale privatization program in the two following years. Property transferred in restitutions amounted to between Kcs 75 and 125 billion. Finally, sales carried out in the small privatization program amounted to Kcs 31 billion. In comparison, the role of foreign direct investment was small as it equalled only Kcs 58.2 billion between 1 January 1990 and 30 September 1993.

In this paper we provide a descriptive analysis of the three privatization programs in the Czech and Slovak Republics. After introducing the relevant institutions in section 1, we examine in detail the background debate, legal basis and implementation of the restitution, small privatization and large privatization programs in sections 2,3 and 4 , respectively. The role of foreign investment is examined in section 5 and conclusions are presented in section $6 .^{1}$

\section{Key Institutions in the Privatization Process}

A number of institutions played a part in the privatization process. Until 1 January 1993, the Federal Ministry of Finance and the Federal Fund of National Property were the important institutions at the federal level. At the national levels, the most important institutions were the Czech and Slovak Ministries of Privatization, Funds of National Property, Ministries of Finance, various founding ministries of state-owned enterprises, and the City and District Privatization Committees, which were created expressly for the sake of privatization.

Ministries of Privatization (officially called the 'Ministry for Administration of National Property and its Privatization') were established in the Czech and Slovak republics after first free elections in the second half of 1990. They have had a broad agenda. First, they were responsible for certain restitution cases by collecting claims for financial compensation and formally approving all decisions to privatize units via auctions within the small and large scale privatization. While the Ministries' role in the process of small privatization was restricted to making simple yes or no decisions, their role in large scale privatization has been a very active one - the Ministries have often entered into negotiations with individuals and institutions submitting privatization proposals and sometimes they have significantly altered 
privatization projects.

The Czech, Slovak and Federal Funds of National Property were established in 1991 as units accountable directly to the relevant Parliaments rather than the executive branches of the individual governments. ${ }^{2}$ They were designed to be the repositories of the financial proceeds of privatization and to make compensation payments within the restitution program. Within the large scale privatization program, they have been the institutions in which property formally changes hands after a privatization project has been approved by all the relevant decisionmakers. In this context, the Funds have not been supposed to alter or renegotiate the terms of the deal.

Many republican (and before 1993 also federal) Ministries have played the part of the founding Ministries. As part of the centrally planned system, each stateowned enterprise was under the jurisdiction of a particular branch ministry. Each of these ministries controlled a given branch of the economy (e.g., manufacturing, heavy engineering, construction, domestic trade, and so on). Since the 1989 revolution, the number of branch ministries has been progressively reduced. In the Czech republic, for example, there is now only one ministry covering industry and trade and one overseeing agriculture. A few enterprises also fall under the ministries of health or cultural affairs.

While still in existence, the Federal Ministry of Finance had two tasks within the privatization process. First, it played the part of a privatization ministry with respect to federal enterprises. Second, it was in charge of organizing voucher privatization (i.e., the distribution of vouchers to citizens, maintaining all the relevant documentation and implementing price adjustments seeking to equalize demand for shares with the given supply). ${ }^{3}$ For this purpose a special branch of the Federal Ministry of Finance, the Center for Voucher Privatization, was established in 1991.

Finally, the republican Ministries of Finance played a part in the restitution process.

\section{Restitution: Returning Property to former Owners}

From the very start of the privatization debate, restitution has been an extremely controversial subject. The advocates of restitution have argued that the reintroduction of private property as a central institution in the economy requires the restoration of the general public's confidence in the constitutional and legal protection of private property. The state must thus demonstrate its determination to protect private property by returning what was unconstitutionally expropriated from private owners.

With the exception of hardline communists and some other highly visible groups, most opponents of restitution basically agreed with the spirit of this argument. They insisted, however, that the price in terms of long-lasting legal disputes (and hence legal uncertainty) would be too high. Moreover, legalizing restitution would open the Pandora's box of further claims, thus hindering any reasonable restructuring, privatization, and establishment of joint ventures by freezing all property transactions (including privatization itself) until property stakes have been de- 
termined. ${ }^{4}$ In the view of these opponents, one may reintroduce private property only after a 'bold line has been drawn below the accounts of the past forty years'. 5

Obviously, a similar debate took place in all the other Central and East European countries. Yet, the only other country that has carried out massive, inkind (natural) restitutions is East Germany, where the process came about principally because of the adoption of the West German legal system [see, for example, Siebert H., 1991]. In contrast, Hungary has for instance focused on financial compensation, with the claimants receiving restitution warranties voucher-like securities entitling the claimants to purchase any privatized property. In this system the claimant therefore has a general right to reacquire property but he/she does not have the automatic right to obtain the very property he/she lost through nationalization.

The Czechoslovak solution is in a sense an intermediate one: it allows the natural restitution of property that was expropriated after the Communist takeover of 1948 but, since a major part of the Czechoslovak economy was nationalized before 1948 , natural restitution accounts for a smaller share of the total nationalized property than in the German case. Moreover, as we discuss below, financial restitutions are permitted only in specific circumstances. ${ }^{6}$

\subsection{The Legal Framework for Restitutions}

At the federal level, the Parliament adopted three major laws dealing with the eligibility for and decisionmaking about restitutions (Table 2). Laws passed at the republican levels dealt with technical or minor administrative problems. After the split of Czechoslovakia, the three federal laws were incorporated into the legal frameworks of the Czech and Slovak republics.

Table 2 - TIMETABLE OF RESTITUTIONS IN CZECHOSLOVAKIA

\begin{tabular}{lcc}
\hline Number and Abbreviated Name of the Law & Valid From & Claim Due Until \\
\hline $\begin{array}{l}\text { No. 403/1990 Mitigation of Property-Related Injustices } \\
\text { No. 87/1991 Out-of-Court Rehabilitations }\end{array}$ & 1 Nov. 1990 & 2 May 1991 \\
$\begin{array}{l}\text { - Returning Property } \\
\text { - Financial Compensation }\end{array}$ & 1 April 1991 & $\begin{array}{l}1 \text { Oct. } 1991 \\
1 \text { Apr. } 1992\end{array}$ \\
$\begin{array}{l}\text { No. 229/1991 Restitution of Land and Other Agricultural } \\
\text { Property }\end{array}$ & 24 June 1991 & 31 Dec. 1992 \\
\hline
\end{tabular}

The three laws have several common features. First, only property nationalized after the Communist takeover of 1948 is to be returned, a principle which excludes property nationalized by the democratically elected government between 1945 and 1948 - the banks, steel industry, insurance companies, factories with more than 500 employees, joint stock companies and some other classes of property. Second, the restitution laws cover only property that was personally (directly) owned by the citizens; property of corporations, cooperatives and other associations is not subject to restitution. Finally, restitution claims could be submitted solely by owners, heirs 
and family members, provided they were Czechoslovak citizens and permanent residents of Czechoslovakia when submitting the claim.

In all three laws, the major approach to restituting property is to transfer it in its present form; in some cases, this system may be substituted for or accompanied by financial compensation. In most cases the claimant has to submit their written request to the present owner (in most cases a state owned enterprise or a cooperative), who is required to hand over the property within a period of time specified in each law. Enterprises with foreign capital participation (being under the protection of Law no. 173/1988) and foreign governments are exempted from this obligation. Private owners are also exempt, provided they acquired the property in accordance with the law valid at the time. In these cases the claimant is entitled to financial compensation paid by the State. In cases where the nature of the property has been significantly altered since nationalization, an additional financial settlement may be required. If the property has been improved, the claimant may opt for financial compensation or receive the property if they pay the difference between the official estimated price of the property before and after the improvement.

Except for a law returning certain property of the Catholic Church, the first law on privatization was the Law on Mitigation of Certain Property-Related Injustices (no. 403/1990), adopted by the Czechoslovak Parliament on 2 October 1990. The law applies to property expropriated in the late $1950 \mathrm{~s}$, primarily on the basis of government decree no. 15/1959 (issued eleven years after the main wave of nationalization). The law applies mostly to real (immovable) property as well as certain types of movable property (chattel) used by the state sector but still officially owned by private individuals on the basis of law no. 71/1959. The law also covers nationalizations carried out by administrative fiat without any legal ground. The law stipulated that claims had to be submitted between 1 November 1990 and 2 May 1991. The current holders of the property were obliged to transfer it to the legal claimants within 60 days.

The Law on Out-of-Court Rehabilitation (no. 87/1991) was passed in February 1991. This law covers a wide range of wrongdoing suffered by Czechoslovak citizens under the communist regime. In the sphere of property rights it repeals all laws and administrative acts from the period 25 February $1948-1$ January 1990 . It also sets the rules for restituting property confiscated during criminal prosecutions of citizens under certain politically motivated laws and for restitutions related to forced sales and cases when citizens gave up property or refused inheritance under government duress. ${ }^{7}$ In practice, courts tended to be liberal in interpreting duress and most 'gifts' to the state could hence be successfully claimed back. Claims had to be submitted within 6 months after the passage of the law (i.e., 1 April-1 October 1991) and current owners were obliged to turn over the property within 30 days of receiving the claim.

The third major restitution law (no. 229/1991), regulating the Restitution of Land and Other Agricultural Property, was adopted in May 1991. This law permits restitutions of property nationalized as part of a land reform, confiscated in connection with criminal prosecution for political reasons, given up as forced sales and 
donations, and refused as inheritance under duress. Moreover, the law applies to cases when property was taken over by cooperatives after property owners joined as coop members. Some of this property remained in the possession of the private owners but it was effectively controlled by the cooperatives or state organizations. The law also stipulates that, unless a different agreement is reached between the legal claimant and the current user of the property, a legally binding rental relationship arises on the day of restitution of the property. This clause gives the current user the right to rent the land at officially set prices. So as not to interfere with the agricultural use of land, any cancellation of this rental agreement must be announced no later than 1 October of a given year for a transfer to be effected in the following year. This clause extends somewhat the reprivatization of land used by cooperatives and state farms.

The focus of the restitution program is on individual citizens, while institutions are generally excluded from its purview. The Catholic Church is a major exception. Unlike the property of major firms in industry and banking, which was nationalized before the Communist takeover in 1948, much of the property of the Church was expropriated in the 1950s. This resulted in an exception granted to the Church in law no. 298/1990 dealing with 'Regulations of Property Rights of Religious Orders and Archdiocese of Olomouc'. By May 1993, 74 items of real estate were returned under this law to the Church. Further restitutions are debated by the Parliaments, where the major issue is whether to establish a rule for the type of property that can be claimed or whether to list specific properties which will be returned to the Church and exclude all else. In the meantime, the former property of the Church is blocked to other forms of privatization.

Minor by the amount of property in question, but major from the moral point of view is the issue of Jewish property confiscated by the Germans in World War II and never returned after 1945. Restitution of this property would go against the rule that restitutions should apply only to property confiscated by the Communist government in or after 1948. It would hence provide a precedent for the return of property to other owners whose property was expropriated before the Communist era. As a result, no law on restitution of this property has been accepted so far.

\subsection{Practical Aspects of Restitutions}

Unlike the small and large scale privatization programs, the implementation of restitutions is to be resolved between the previous and present owners, without any direct role of the central authorities. The Czech and Slovak governments therefore do not even possess accurate data on the extent of effected restitutions. The estimates released by the Czech government cover the period to the end of 1992. According to these estimates, about 30,000 items (mostly industrial enterprises) have been returned from nationalizations carried out between 1948 and 1955, and approximately 70,000 items (mostly apartment buildings) have been returned from the property that was nationalized between 1955 and 1959 .

The restitution of enterprises on the basis of the law on Out-of-Court Rehabilitations have had an impact on large scale privatization discussed later. The 
previous owners, having the right to claim a part of present enterprise, can enter into negotiations with the management, other interested buyers or authors of privatization projects, or they can submit their own privatization project. They can receive a share of the enterprise on the basis of their restitution claim and they can also buy another part or the rest of the enterprise. The official policy was that in these cases the restitution claimants can be given a priority over outsiders. For instance, they can buy the property for its estimated price (based on book value) and need not compete for the property in public auctions.

Agricultural property has turned out to be the most problematic item in the restitution program. The legal requirement to register land transactions was discontinued in 1951 and evidence on land property is therefore incomplete and inaccurate. ${ }^{8}$ According to recent official estimates, 200,000 claims to restitution of agricultural property were submitted in the Czech Republic alone, but as of March 1993 only one-third of these claims was settled. Yet, the resolved claims have been substantial as about one-half of state-owned forests and agricultural land (used mostly by cooperatives) has already been returned.

Table 3 - NUMBER OF RESTITUTIONS AND OTHER FORMS OF PRIVATIZATION OF RETAIL TRADE COOPERATIVES

\begin{tabular}{lcccc}
\hline & Restituted & Leased & Sold & $\begin{array}{c}\text { Total Avail- } \\
\text { able }\end{array}$ \\
\hline Total & & & & \\
- CR & 5214 & 2216 & 3767 & 24146 \\
- SR & 135 & 358 & 44 & 11861 \\
Retail shops & & & & \\
- CR & 1936 & 1287 & 2101 & 16399 \\
-SR & 70 & 108 & 30 & 8158 \\
Restaurants & & & & \\
- CR & 3278 & 929 & 1566 & 7747 \\
-SR & 65 & 250 & 14 & 3703 \\
\hline
\end{tabular}

Source: Tydenik Hospodarskych novin 27/1991. The total number of units is recorded as of 31 December 1990. The other data refer to 31 March 1991 in the Slovak Republic and 4 April 1991 in the Czech Republic. Restitutions according to law no. 403 continued until 2 May and in certain cases until 31 August 1991. Law no. 87/1991 was approved later and resulted in many additional new entitled claims.

An important source of information about restitutions are reports by owners of nationalized property who had to return their property to previous owners. Table 3 contains information about the impact of restitutions on retail trade cooperatives. As can be seen from this table, although the deadline for submitting restitution claims based on the first restitution law was 2 May 1991, many restitutions were carried out well before this deadline. In interpreting the data in Table 3, one must also remember that cooperative restaurants and retail shops were dominant in rural areas but quite rare in the cities. The data hence indicate that within the first ten months of the privatization program, most restaurants in the Czech countryside were privatized, with restitutions accounting for more than one-half of the privat- 
ized units. In contrast, privatization of retail shops proceeded slower and restitutions were less important. There is a historical reason for this asymmetry as many retail shops had been owned by coops before the forced 'collectivization'. Rather than nationalizing, the communist regime created highly centralized coops by combining both private shopkeepers and the independent coops. Finally, one can see from Table 3 that restitutions as well as other forms of privatization of cooperative restaurants and retail shops proceeded much more slowly in Slovakia than in the Czech lands.

\subsection{An Assessment of the Restitution Program}

Restitution was intended to be a relatively less important privatization program than small and large scale privatization and there were fears that its implementation would hinder the other two programs. As it turned out, in the first two post-revolutionary years restitution played a much more important part than was ever expected. In privatizing the small business sector, for instance, restitutions dominated the sales of state property that were carried out within the small scale privatization program. The fears that restitutions would block privatization also proved only partially justified. The limitation of restitutions to property nationalized after February 1948 left a large part of state property to be privatized by other methods, while the amount returned was large enough to have a significant impact on the development of the private sector before the other privatization programs were started. Recent official estimates of the relative size of the returned property range from $10 \%$ to $25 \%$ of all state-owned apartment buildings and retail shops.

Restitutions based on the law on Out-of-Court Rehabilitations have also covered significant assets in industry and they have had a strong impact on large scale privatization. Previous owners have submitted 397 separate privatization projects in the first wave of large scale privatization, which in turn involved over 2,800 enterprises.

Needless to say, decisions as to whether properties ought to be returned or privatized through other means were not always clear and clean. The best known problematic case was the disputed sale of the state-owned enterprise Rakona to Procter \& Gamble. This factory was nationalized in 1946 by the democratic government, but the former owners filed a suit, disputing the legality of the nationalization decision. The case was unfinished at the time of the 1948 communist takeover and the communist authorities simply reconfirmed the 1946 nationalization decision. The heirs of the pre-1948 owners reopened the case after the 1989 revolution, claiming that the 1946 appeal was not resolved and that the communist government hence nationalized the company after 1948. If this interpretation were to be found correct, the heirs would have a possible restitution claim. The Czech Ministry of Privatization rejected this interpretation, however, and sold Rakona to Procter \& Gamble on the assumption that the 1946 nationalization decision was valid and no restitution claim was thus possible. The heirs have challenged this decision and at the time of the writing of this paper their appeal is with the court. In spite of the court's decision in favour of the state, the dispute is not likely to be resolved earlier 
than next year.

Another problematic area is that of restitutions in agriculture. As we already mentioned, proper documentation is often unavailable and the validity of restitution claims thus tend to be unclear. Unlike in housing, retail trade or catering, where restitutions have contributed to a fast start of the privatization process, in agriculture they have tended to slow down the process of restructuring cooperatives and privatizing state-owned land.

Overall, despite the various problems that have arisen in the course of restitutions, the evidence is overwhelming that restitutions have provided a great initial boost to the privatization program and succeeded in privatizing an unexpectedly large part of nationalized property. They have been also highly complementary to the other parts of the overall privatization program.

\section{Small Scale Privatization}

Small scale privatization is the Czech and Slovak counterpart of Hungarian preprivatization. ${ }^{9}$ Its introduction in Czechoslovakia as a separate part of the privatization process was motivated by two factors. The first one was technical, namely that the preparation of a legislative, financial and institutional framework for large scale privatization required time. The time requirement was seen as substantial for both voucher schemes and Treuhand-like privatizations. The auctioning of retail shops and small businesses was hence viewed as a feasible and rapid way to launch the privatization process.

Table 4 - ATTITUDES TOWARDS PRIVATIZATION (in \% of each group)

\begin{tabular}{lccc}
\hline Group of Respondents & $\begin{array}{c}\text { No or } \\
\text { individual }\end{array}$ & $\begin{array}{c}\text { Small } \\
\text { Firms }\end{array}$ & $\begin{array}{c}\text { No } \\
\text { Limits }\end{array}$ \\
\hline Total & & & \\
Residents of the Czech Republic & 18.6 & 46.5 & 34.9 \\
Residents of the Slovak Republic & 15.9 & 47.7 & 36.4 \\
Voting preference: Civic Fonum, PAV & 23.5 & 44.4 & 32.1 \\
Voting preference: Communist Party & 10.7 & 46.4 & 42.9 \\
\hline
\end{tabular}

Note:

No or individual: Either no private enterprises should be allowed, or they should be restricted to self-employed individuals only.

Small firms: Agree with private firms of small size, ranging from several to a maximum of 50 employees.

No limits: Private enterprises of any size should be allowed.

Source: AISA.

The second reason for launching small scale privatization was political. In the immediate post-revolutionary period, privatization of a major part of the economy was a controversial issue. The communist party was still powerful in the government and had almost a majority in the parliament until the first free elections in June of 1990. However, the privatization of retail shops, small services, restaurants and the rest of small businesses was acceptable even to the communist party and 
most of its electorate. As can be seen from Table 4, this support was not overwhelming, however, since in January 1990 over $45 \%$ of communist party voters were in fact against any private ownership other than self-employed individuals. ${ }^{10}$

\subsection{The Legal Framework for Small Scale Privatization}

Small scale privatization was officially launched by the federal law on the Transfers of State Ownership of Certain Goods to Other Legal or Physical Persons (no. 427/1990), ${ }^{11}$ passed on 25 October 1990. The law permits the sale or leasing of real and movable property possessed by state-owned enterprises and federal, republican and local governments. To be eligible for privatization under this law, the property must be a 'business unit', defined in the law as properties which 'form or may form sets which are complete economic and property units'. The law stipulates three additional pre-conditions for a property to be admissible to small scale privatization:

- the right of use of the property is not leased or transferred to foreigners;

- the unit is not in agricultural production; and

- the property is not subject to restitution.

In those cases where the business unit (for example, a shop) is privatized without property rights to the building and land on which it operates, a two-year lease is guaranteed by the state (e.g. if the building is acquired by a new owner, this owner is obliged to honour the old lease for its legally fixed period of time). ${ }^{12}$

In spite of the term 'small' privatization, there are no legal limits on the size of the property to be privatized in this program. Some of the sales carried out within small privatization were in fact quite large (e.g. the Urpin Brewery in central Slovakia was sold for Kcs 320 million, or about US\$10.8 million).

In small privatization, property may be transferred only to 'natural' (individual) persons who are or were citizens of Czechoslovakia after 25 February 1948 and who are permanent residents of the Czech or Slovak republic. ${ }^{13}$ Companies formed by such persons are also eligible but other (especially state-owned) enterprises are not.

The only permissible method of privatization under this law is public auction. If a business unit fails to be sold in a public auction, another auction is organized and foreigners may participate. Persons wishing to join an auction are required to pay an entry fee of Kcs 1,000 (about US\$35). In order to bid for an item, one must make an auction (escrow) deposit equal to $10 \%$ of the item's starting auction price.

Auctions are conducted by District or City Privatization Committees, ${ }^{14}$ whose members are nominated by the Ministries of Privatization of the Czech and Slovak republics. To ensure that information is publicly available, the list of objects that are to be auctioned must be published 30 days before the auction. The list must contain a description of each unit, its location, present owner, book value, and conditions under which interested persons can inspect the unit. Inventory of items in the unit's stores (the value of which is not included in the unit's auction price) as well as the extent and terms of credit on these items must also be listed.

The present owner-custodian of a unit that is to be privatized must submit a 'privatization sheet', containing all the information required by law. These owners 
(mostly state or municipally-owned enterprises or cooperatives) play for the most part a passive role. Their only tool to hinder privatization is a late submission of the privatization sheet. The privatization committees, on the other hand, are rather powerful: if anyone, through the privatization committee, requests the auctioning of a part of any enterprise which is subject to the law on small privatization, the enterprise is legally obliged to give the business unit up for auction or provide an explanation as to why this is impossible. Each privatization sheet is then submitted through the branch ministry to the Ministry of Privatization of the republic, which issues a permit for the auctioning of the unit.

The organization of auctions has been centralized in order to prevent legal difficulties, which could be caused by wildcat auctioning of properties. In practice, many legal problems have arisen despite the centralized organization. ${ }^{15}$ All auctions are of the English style, with the price rising in the presence of two or more bids. If no one expresses interest in purchasing a unit at the starting price, a Dutch auction is allowed under certain conditions. In this auction the auctioneer announces a starting price and continuously reduces it until someone accepts. Several restrictions have been imposed on the use of the Dutch auction: there must be at least five potential buyers present, the price cannot fall below $50 \%$ of the starting price (unless it is a repeated auction), and since October 1991 buildings and land have been excluded from Dutch auctions. The resulting price must be paid by the successful bidder within 30 days of the auction: the payment for the auctioned property goes to the Fund of National Property, the payment for the value of the inventories (if purchased as well) goes to the previous owner. If the buyer fails to pay on time, the purchase is void. ${ }^{16}$

Small scale privatization also has certain unusual legal features. For instance, no liabilities, such as labor contracts, debts (except those for the inventory) and other obligations (except the obligation to continue selling food in the case this was the original line of business) are transferable with the property. They remain with the previous owner, i.e., mostly state-owned enterprises.

\subsection{Small Scale Privatization in Action}

The first auctions were held on 26 January 1991 in Prague. The first auctions in the Slovak Republic took place one month later, on 24 February in Bratislava. In the Czech republic, small scale privatization had been finished at the end of 1993 . Even earlier, in second half of 1992, it had lost its importance in favour of large scale privatization. In comparison with several thousands of units sold every quarter in 1991 and early 1992, in late 1992 only around one thousand were auctioned. Within the first six months of 1993, small privatization amounted to only 646 units in whole Czech republic. The end of small scale privatization in the Slovak republic has not yet been announced.

As can be seen from Table 5, most of the auctions took place in 1991 and early 1992. Small scale privatization thus effectively preceded large scale privatization which gained momentum in 1992. The table also captures the dynamics of the small privatization process. Approved units are those which were proposed for 
privatization and approved by the Ministry of Privatization. Since the implementation of privatization after the official approval is usually a lengthy process, at any point in time the number of actually privatized units is much smaller than the number of approved units. Person(s) who lease a unit that is to be privatized before a set deadline have a priority right to purchase the unit. Some units were hence sold rather than auctioned.

An important criticism of small scale privatization stressed that it consisted primarily of selling leases instead of selling real property. As can be seen from Table 5, this was indeed the case at the start of the process. However, the proportion of units sold as real property (i.e. with land) was growing monotonically over time and in the second half of 1992 almost $50 \%$ of all sales were with land. Given the currently elevated land prices, it is not surprising that most proceeds from small scale privatization came from the sales of units that included real property.

The course of small scale privatization in Slovakia showed a similar pattern to that in the Czech republic - a rapid acceleration in the second half of 1991 and deceleration during 1992. Slovakia also experienced a somewhat greater lag in implementation as only 11,424 units were actually privatized by 30 October 1992 . Of these, 9,306 were privatized through auctions, with the total value based on the starting price being $\mathrm{Kcs} 12.1$ billion and value based on the final price being Kcs 14.2 billion.

\subsection{What has Small Scale Privatization Achieved?}

Like restitution, small scale privatization played an important role in privatizing the Czechoslovak economy. Tens of thousands of units were sold within the program of small scale privatization (see Table 5), thus contributing significantly to the overall goal of the privatization program.

Given that its implementation was based on auctions, small scale privatization could hardly have become the main tool of the entire privatization process. Since the goal of privatization was to distribute property primarily to Czechoslovak citizens, public auctions could not have served effectively as tools for privatizing large industrial enterprises. As it was administered, small privatization required bidders to commit significant financial resources, an aspect that was often criticized for preventing new entrepreneurs from participating in the program. Since many bidders significantly leveraged their positions, the program was also criticized for endangering the future of the sector by exposing it to unnecessarily high frequency of bankruptcies. Finally, a critical limitation of small scale privatization was that the law restricted purchases solely to physical property, excluding most other assets and liabilities.

The first of these criticisms was partly offset by the relatively liberal credit posture adopted by the major banking institutions. Credit was especially earmarked for private businesses and, particularly in connection with small scale privatization, 


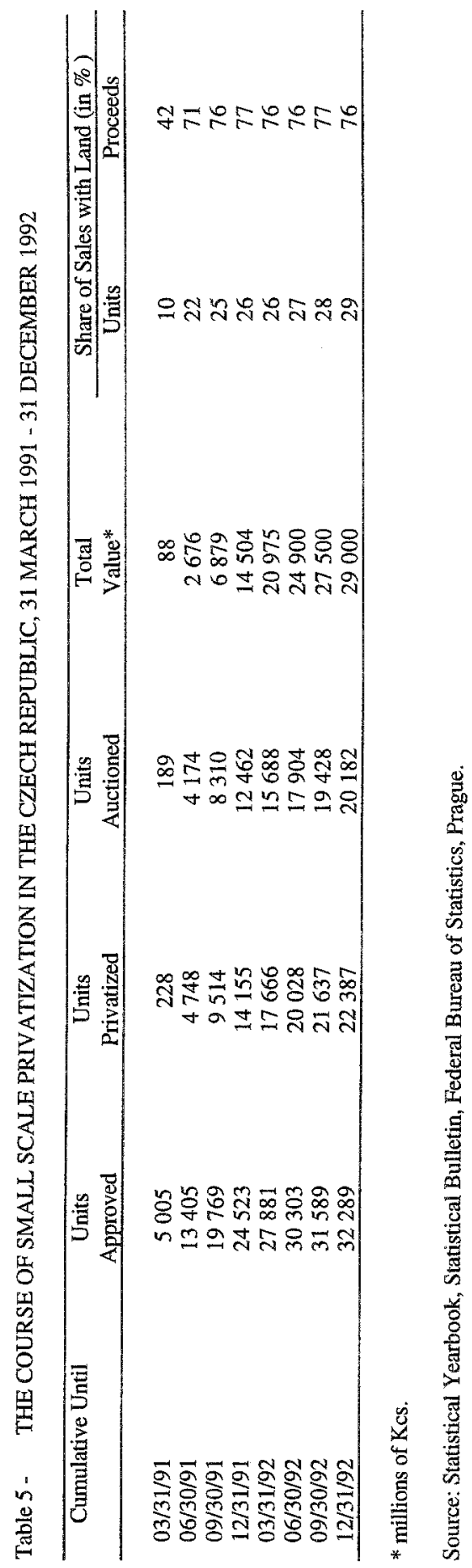


it was increasing rapidly since early 1991 . However, interest rates (relative to most other costs of production) were high and the financial burden of credit was thus heavy. 17

A major advantage of small scale privatization was its simplicity, speed and countrywide coverage, which provided a signal to the general public that the government was serious about privatization. Together with restitutions, small privatization succeeded in privatizing the bulk of retail distributorships, catering and other services. It re-established the middle class of small entrepreneurs that was completely wiped out by the communist regime. Finally, although a significant share of the government revenue came from transactions based on bank loans extended to the buyers, small privatization had a significant contribution to public finances, amounting to Kes 31.6 billion in the Czech republic and more than Kcs 14 billion in the Slovak republic during the 1991-1992 period.

\section{Large Scale Privatization}

\subsection{The Debate and Proposals}

The discussion about the merits and modalities of large scale privatization started soon after the collapse of the communist regime. In the first months there were several competing groups of proposals discussed in the government and the public. The most widely debated ones were the following:

1. At least in the short term restrict privatization to smaller units. Commercialize large enterprises by separating their budget and management from the state and place emphasis on improvements in management. Privatization is to be based on the firm's business plan and should use standard (Treuhand-like) methods of privatization: direct sales, creation of joint ventures, leasing and so on;

2. With the exception of small businesses, transfer the property rights over firms to employees. This could be done in a 'big bang' form by declaring the firms to be worker-owned, or gradually by introducing some form of employee stock ownership plans - ESOPs.

3. Distribute the property for free or for a negligible fee to citizens at large. ${ }^{18}$ The primary goal is the speed of privatization and its social acceptability (equity). Management and restructuring problems will be tackled by the new owners. Prevent spontaneous privatization (free takeover of firms by management) for reasons of equity and social acceptability.

\subsubsection{Proposals Emphasizing Commercialization and Limited Privatization}

Proposals belonging to the first category were plentiful and had supporters both within the first non-communist government and among the managers of stateowned enterprises. ${ }^{19}$ The most prominent proposals of this type were the following:

1(a). A proposal prepared in an internal document by a group of experts for the government of Czech Republic. This proposal placed emphasis on separating enterprises from the state budget and creating a powerful governmental 
agency for administering national property. Privatization was to be considered a long term process, lasting several years or even decades;

1(b). A proposal submitted by a group of experts of the Czechoslovak Deputy Prime Minister, Valtr Komarek. ${ }^{20}$ This proposal was in many respects similar to the first one but it adopted a more tolerant attitude toward spontaneous privatization. ${ }^{21}$ The law on State-Owned Enterprise (no. 111/1990) of April 1990 was drafted by this team and it permitted the transfer of property of state-owned companies to other companies, without imposing strict conditions. In practice, this paved a way for the possibility of transferring state property to the management. As a result, this provision of the law was later abolished;

1(c). A proposal of the Union of Industry, a forceful pressure group of the top management of state-owned enterprises. ${ }^{22}$ The core of this proposal was based on similar ideas as the two previous ones but it added two features favoring current management and employees:

- the agency for administration of state-owned enterprises should at least partly be controlled by deputies of firms and employees; and

- each firm should be privatized according to the decision of the firm's management and the revenue gained from privatization should serve as a source of income for the firm;

1(d). A proposal to rely on leasing as the main tool of privatization. This proposal has been repeatedly but always unsuccessfully submitted by some members of the Parliament.

\subsubsection{Proposals Emphasizing Worker Ownership}

Proposals falling within the second (worker participation and ownership) category enjoyed historical prominence in Czechoslovakia. The 1968 economic reform, interrupted by the Soviet tanks, contained a spontaneous element of employee control. The cooperative movement also had long historic traditions in the country. After the 1989 revolution, these proposals were backed by a number of political parties and other groups:

2(a). Labor-management played a significant role in the Social Democratic Party's election program in both the 1990 and 1992 elections, ESOPs were an important element in the 1992 program of the 'Liberal Social Union' and partly in the program of the Communist party;

2(b). Employee ownership was extensively discussed in the (religiously oriented) Czechoslovak Peoples Party in 1990;

2(c). Employee ownership was also advocated by Ota Sik, a prominent economist active in the 1968 reform [see e.g., Sik O. (ed.), 1990];

2(d). Self-Management was the main theme of the Movement for Self-managed Society, whose proposals were based on ideas from the large literature on self-management and directly inspired by Jaroslav Vanek, a leading researcher and propagator of these ideas [see e.g., Vanek J., 1990];

2(e). Until mid-1990, ESOP plans were discussed within government and em- 
ployee ownership was listed as one of the privatization methods in some of the early 1990 government documents. After the June 1990 election victory of the Civic Forum, a movement broadly oriented toward introducing a market economy, the ESOP and labor-management proposals lost part of their support as private property-based reforms gained greater popular appeal. The law on State Owned Enterprise even removed some institutions of labor management which were introduced within the communist government's attempt at economic reform in the 1980s.

\subsubsection{Proposals Stressing the Distribution of Property to Citizens at Large}

Proposals for mass privatization started gaining support from early 1990. The first of them, prepared by Svejnar (1989), appeared in the Czechoslovak context as early as December 1989-January 1990 . The following strategies of distribution of companies' shares were discussed in Czechoslovakia:

3(a). Transform state-owned enterprises into joint stock companies and distribute a significant portion of their shares to citizens at large in the form of diversified portfolios. To make the distribution manageable, prepare partially diversified portfolios of enterprise shares in the form of (private or public) mutual funds and give each citizen a portfolio of shares of these funds into a computerized account. This allocation can be made virtually instantaneously, is equitable and does not require pricing of shares. It minimizes the exposure of individuals to risk and provides new entrepreneurs with a stock of wealth that can be used as a collateral for loans. Remaining shares can be distributed to pension and health insurance companies, as well as to local government or other entities. Voluntary trading of enterprise and mutual fund shares could start immediately after the computerized distribution and it would lead to a market-based determination of share prices [Svejnar J., 1989].

Similar proposals were (and still are) discussed in Poland [see e.g., Lipton D. and J. Sachs, 1990 or Frydman R., Rapaczynski A. and J.S. Earle, 1993].

3(b). Distribute shares of individual enterprises to individuals through holding companies, so that each firm would be controlled by one of these companies [see Blanchard O. et al., 1991].

3(c). Issue free or almost free vouchers to individuals, entitling them to bid for shares of any firm slated for privatization. This method needs to determine share prices and tends to be iterative in nature. It leaves the bidding decisions to the citizens who choose to participate in the program and the price adjustment decisions to the government. It is time consuming and exposes the participating individuals to all the undiversified risk as well as the benefits of learning-by-doing.

\subsubsection{The Adopted Program}

The adopted program of large scale privatization has been quite flexible in terms of the permitted privatization methods. The program allows direct sales, 
auctions, transformations into a joint stock company and sale or voucher distribution of shares, or a combination of the various methods. Within the voucher scheme citizens can either allocate their vouchers into mutual funds or bid with their vouchers for shares of specific enterprises. Privatization projects may also propose that up to $10 \%$ of enterprise shares be sold to workers in the firm.

Unlike in the plans discussed in Poland, mutual funds are established voluntarily by private or government-owned organizations (for example, banks) on the basis of their own decision to run such a fund. On the other hand, flexibility in the use of vouchers does not go as far as in the Russian case - vouchers are issued separately for each one of the two waves of large scale privatization and they cannot be used for any other purchases (for example, for purchases of property in small scale privatization).

\subsection{The Legal Framework for Large Scale Privatization}

The legal base for large scale privatization consists of several laws and a number of administrative regulations. The federal law on Conditions for Transferring State Property to Other Persons (no. 92/1991), ${ }^{23}$ passed on 26 February 1991 and became effective in April 1991. It gives basic guidelines for the privatization of state-owned enterprises, banks, insurance companies and other institutions. The law also covers the privatization of shares and other property assets owned by the state or the above institutions in other enterprises (for example, the Czechoslovak government's property share in joint ventures). Unlike in restitution, new owners can be both domestic or foreign entities. Unlike in small scale privatization, the privatized property includes all assets, liabilities and claims towards the enterprise as well as all contracts. Wage and other agreements hence stay with the enterprise through privatization. The only exceptions relate to property falling within natural restitution, property privatized in small privatization and areas where the law requires state ownership.

Large scale privatization may be carried out through one (or a combination) of five permissible privatization methods:

- transformation of a state-owned enterprise into a joint stock company and a transfer of shares (e.g., through voucher privatization);

- direct sale to a predetermined buyer;

- public auction or public tender;

- free (of charge) transfer to municipal ownership; and

- free (of charge) transfer to social security, health insurance and other publicly beneficial institutions.

Transformation of a state-owned enterprise into joint-stock company is quite differentiated; shares may be distributed through voucher privatization to citizens, sold directly to a domestic or foreign owner, sold through intermediary (stock exchange, over-the-counter RM system or other financial institution), transferred for free to municipalities, health insurance companies, sold to employees or issued to former owners as compensation of their restitution claims. Moreover, a part of the shares are kept temporarily or permanently by the Fund of National Property. 
Whereas the former ownership of FNM usually indicates that negotiations with foreign or partner are in progress and shares will be sold after agreement is reached, permanent ownership is intended to preserve state influence on key enterprises. This may be achieved even with low number of shares held by FNM, since Czech law recently introduced the institute of a golden share. Approval of its owner is needed for certain key decisions, specified in company's status.

Privatization of each enterprise is based on an officially accepted privatization project. According to the law, all state-owned enterprises must be classified as either being slated for the first or second wave of large scale privatization or as being temporarily exempt from privatization. ${ }^{24}$ Each enterprise selected by the government for privatization in one of the two privatization waves is required to submit a basic privatization project (proposal). The responsibility for preparing the project lies with the founding institution (usually a ministry). However, the project is usually designed by enterprise management.

Any local or foreign institution or individual can present a competing project which, if it meets certain requirements, will be considered on an equal footing with the basic project by all authorities involved in the privatization process. The founding ministry evaluates all the submitted projects that fall under its jurisdiction and passes its evaluation for the final decision to the republican Ministry of Privatization. ${ }^{25}$ In some cases (for example, when a foreign entity directly buys the enterprise), the decision is taken by the republican government rather than by the Ministry of Privatization.

The privatization projects must describe the proposed organization of the privatized enterprise and the proposed method of privatization. Projects also have to contain information about the enterprise's recent history: for projects submitted in the first wave this information related to employment, wages, capital, sales, costs, profit, and foreign trade during the $1989-1991$ period ${ }^{26}$ In order to enable the proposers of competing projects to obtain and furnish the necessary information, managers are required to provide the relevant information upon request.

The transaction price of an enterprise varies with the method of privatization and the status of the potential buyer. The book value of the firm has to be stated in all projects and a copy of the balance sheet of the enterprise must be attached to each proposal. Land and other real assets must be priced according to valid pricing regulations, ${ }^{27}$ resulting in prices which in most cases differ significantly from the corresponding book values. For public auctions, tenders or direct sales to domestic buyers, the book value is taken as the basis for the starting or sale price. In the case of transformations of state enterprises into joint stock companies, the book value determines the book value of equity. Foreign buyers must also submit a price estimate based on an audit by an independent accountant, which is then subject to further negotiations. The lawmakers intended this provision as an advantage for local buyers; in practice the book value is often dubious and both domestic and foreign buyers tend to use price estimates by auditing firms when approaching direct sales.

After the privatization project has been approved, the property of the stateowned enterprise is transferred to the republican Fund of National Property. ${ }^{28}$ This 
transfer legally amounts to a dissolution of the firm (without being formally liquidated by the founding ministry) and founding of a new firm by the Fund. The Fund then sells or transfers the property by method(s) proposed by the approved project. In the case of some joint stock companies privatized in the first wave, the approved privatization projects stipulated that the Fund would retain part of the property. The Fund's assets and their yields are separate form the government budget.

\subsection{Large Scale Privatization: Scope and Results}

Large scale privatization covers most state-owned assets in industry, agriculture and trade. Using data from the Czech Republic for illustration, the 1990 official book value of all capital in the Czech Republic was Kcs 2,604 billion (about US\$95 billion). In comparison, the book value of enterprises for which at least one privatization project was submitted by March 1992 was more than Kcs 1,000 billion. In Table 6 we show the number of enterprises slated for privatization and the fraction that entered the first wave which took place in 1992. As can be seen from the table, over one-half of the eligible firms entered the first wave.

Table 6 - FIRST WAVE OF PRIVATIZATION: ENTERPRISE DATA BY REPUBLICS (number of State Enterprises)

\begin{tabular}{lccc}
\hline & CR & SR & CSFR \\
\hline Eligible for Privatization & 4,400 & & \\
Entering First Wave & 2,210 & 1,600 & 6,000 \\
Offered in Voucher Scheme & 988 & 900 & 3,100 \\
\hline
\end{tabular}

Note: The frst two rows are based on 1991 government estimates. All numbers refer to the situation in 1991. Since then, many state-owned enterprises have been divided and the present number of enterprises is much higher. The third row gives numbers of enterprises with headquarters in each republic. Of the 988 firms located in the Czech Republic, for instance, 45 were founded by federal organizations. Hence only 943 submitted privatization projects to the Ministry of Privatization of the Czech Republic.

The first steps leading to large scale privatization were carried out in 1991 since the relevant law dates to 1 April 1991. However, the entire process of privatizing a firm (including the preparation of the project, processing by founding ministries, approval by the privatization authority, and finally the transfer of the property to a new owner) turns out to be very lengthy.

First, the list of enterprises to be privatized was compiled by the founding ministries and approved by the government. This list, published in June 1991, divided all firms into the following categories: firms to be privatized in first or second wave of privatization, firms to be privatized later (after more than five years) and firms to be liquidated. Projects for the first wave had to be submitted by 31 October 1991 but the deadline was extended for competing (non-management) projects until 20 January 1992, when the approval process started. Projects for the second wave had to be submitted by 16 July 1992 with the exception of firms in a health related industry.

Within this timetable, it took nearly a year before the process generated results. 
For instance, only 27 projects were approved in the Czech republic in 1991. Of these, 20 resulted in the transfer of property in the same year $(5$ firms were sold in auctions, 2 were sold in public competitions, 5 were sold directly, and 8 cases involved the sale of shares of a state-owned joint stock company). Yet, the massive work undertaken in 1991 resulted in a breakthrough in 1992. As can be seen from Table 7, almost 4,000 privatization projects were approved in the Czech Republic alone in 1992. Needless to say, the implementation of privatization by the Funds of National Property lagged somewhat behind the approvals. On 31 December 1992, for instance, $36 \%$ of approved projects were implemented, with another $24 \%$ of projects being realized through the voucher privatization scheme discussed below. The resulting property transfer took place on 29 March 1993 in Slovakia and on 24 May 1993 in the Czech republic.

Table 7 - PROGRESS OF LARGE SCALE PRIVATIZATION IN 1992 IN THE CZECH REPUBLIC: APPROVED PRIVATIZATION PROJECTS*, 1991-1993 (cumulative number)

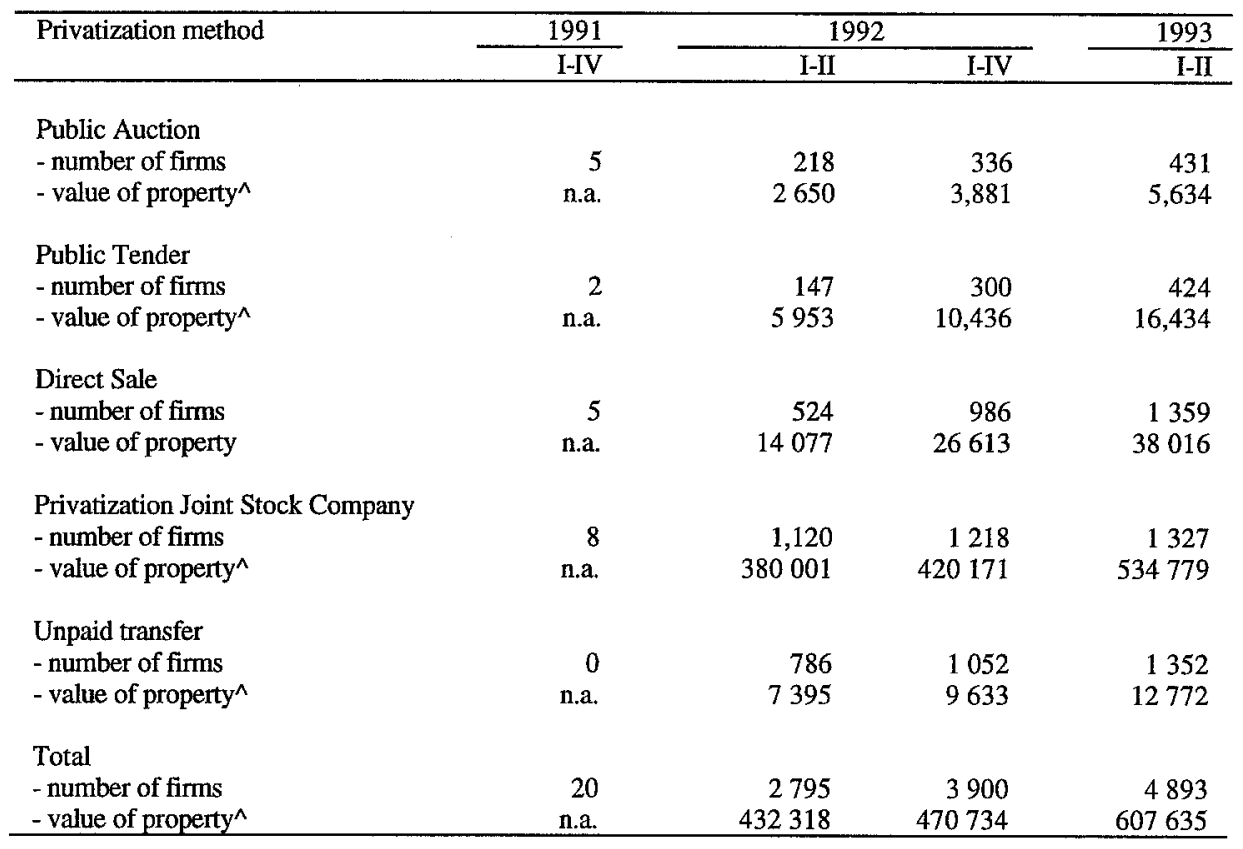

* Former federal property is not included.

$\wedge$ million Kcs

Source: Ministry for Privatization of the Czech Republic.

As can be seen from Table 7, the single most frequently approved method of privatization was the privatization of joint stock companies. Voucher privatization was in turn the most frequently used method within this category. The other most important methods of privatization were direct sales, public tenders and free (of 
charge) transfers to municipalities and health, social insurance and other publicly beneficial organizations. Finally, public auctions also accounted for a number of privatization.

After the approval rush in the second quarter of 1992, caused by the deadline set for the approval of projects for the first wave of voucher privatization, the privatization process slowed down and in the fourth quarter of 1992 it virtually stopped. While Kcs 366 billion worth of property was approved for privatization in the second ('voucher') quarter of 1992, Kcs 32 billion worth of property was approved in the third quarter, and only Kcs 6.4 billion in the fourth quarter.

This slowdown was brought about by several factors. First, after the June 1992 elections, a new administration came to power in both republics and at the federal level. Unlike in Slovakia, there was only a minor shift in the political composition of the government in the Czech Republic, but new Ministers of Privatization came to office in both republics. Probably more significant was the fact that the least problematic projects were easily approved first, with the more difficult ones remaining to be resolved later. As can be seen from the Czech republic data in Table 8 , most of the first wave projects were either approved or rejected by 30 October 1993. However, for 102 firms (out of 2,431) all projects were rejected and whole process of submitting and approving has to start again. Moreover, nearly 400 firms were still waiting for a decision. Among the second wave projects, only one third was decided in October; the speed of the approval process had been accelerated just around that date, since the supply of firms for the second wave of voucher privatization has to be finalized by February 1994.

The slowdown was also caused in part by the publicity surrounding first privatization scandals which appeared together with demands for the reversal of several decisions. ${ }^{29}$ Finally, although legislators expected privatization decisions to be simple, with only one privatization project being frequently submitted for a given firm, 11,315 projects were in fact submitted for 2,431 firms in the first wave. For most firms the authorities had to select from a number of competing proposals, thus requiring significant time for the approval process.

Table 8 - NUMBER OF LARGE PRIVATIZATION PROJECTS AND PRIVATIZED ENTERPRISES IN THE CZECH REPUBLIC AS OF 31 MARCH 1993

\begin{tabular}{lccrrr} 
& \multicolumn{2}{c}{ First wave } & & \multicolumn{2}{c}{ Second wave } \\
\cline { 5 - 6 } & Projects & Firms & & Projects & Firms \\
Projects submitted & 11315 & 2431 & & 12004 & 2052 \\
Decision reached & 10121 & 2032 & & 4924 & 913 \\
Projects approved & 3531 & 1930 & & 2683 & 819 \\
Project rejected & 6590 & 102 & & 2241 & 94 \\
Undecided & 1194 & 399 & & 7080 & 1139 \\
\hline
\end{tabular}

Source: Report of Ministry of Privatization of the Czech Republic.

The fact that the approval of a privatization project often resulted in a break-up of a state-owned firm into several parts, with each being possibly privatized by a 
different method, also explains the difference in the data between Tables 7 and 8 . Table 8 gives the number of privatization projects and the number of firms entering large scale privatization. Table 7 shows how the various units resulting from approved projects were going to be privatized.

Another important feature of Czechoslovak privatization was its openness towards general public. As can be seen from Table 9, outside bidders submitted 39\% of all privatization projects, followed by the management of the companies with $25 \%$ of projects. In terms of success, it turns out that the management proposals were the most successful ones, resulting in a majority of the approved projects.

Table 9 - PROPOSERS OF PROJECTS IN THE CZECH REPUBLIC (31 December 1992)

\begin{tabular}{lcc}
\hline Project Submitted by & Total number & Percentage \\
\hline & & \\
Management of Company & 2813 & 25 \\
Management of Plants & 450 & 4 \\
Bidders for Purchase of Company & 4388 & 39 \\
District Privatization Commission & 788 & 7 \\
Restitution Claimants & 450 & 4 \\
Local Government & 450 & 4 \\
Consulting Firms & 338 & 3 \\
Others & 1575 & 14 \\
Total & & \\
\hline
\end{tabular}

Note: Bidders for the purchase of a company are proposers of competing projects who wish to purchase the company.

Consulting firms submit projects proposing sales to other entities or apply to obtain a contract to organize a tender or auction.

\section{Voucher Privatization}

The law on Large Scale Privatization (no. 92/1991) allows for the distribution of shares of joint stock companies to citizens through vouchers. Decree no. 383/1991 of the federal government from 5 September 1991 defines the technical procedure of voucher privatization, describes how eligible individuals can obtain vouchers and sets guidelines for the functioning of Investment Privatization Funds (IPFs) mutual funds to which the holders of vouchers can allocate their voucher points for investment.

The process of voucher privatization fits into the two waves of large scale privatization. Within each wave about one-half of the enterprises slated for voucher privatization are offered for privatization in several rounds of bidding. The voucher scheme consists of a matching of bids by voucher holders with a fixed number of shares supplied by each enterprise. The authorities adjust share prices in terms of voucher points between individual rounds in an attempt to match the demand for shares with supply, thus hoping to sell many firms fast.

Enterprises are selected for voucher privatization on the basis of privatization projects. In the first wave the privatization authorities set a rough goal in terms of how much book value of enterprise assets should go into voucher privatization and 
indicated to what extent they would favour projects allocating a part of shares into the voucher scheme. In the process of preparing projects, many enterprise managers as well as others consulted with the founding and privatization ministries and adjusted the proportion of shares allocated for vouchers so as to increase their chances of approval. Hence, the voucher scheme was to some extent an iterative process already in the phase of project preparation. In the process of reviewing projects, privatization ministries submitted information to the Federal Ministry of Finance which was in charge of coordinating the voucher scheme.

The demand side of voucher privatization is represented by individual investors and IPFs that use their voucher points to bid for the available shares. Since late 1991, post offices all over Czechoslovakia had a supply of voucher books to be used in the first wave in 1992. Every Czechoslovak citizen over the age of 18 and residing permanently in Czechoslovakia could register one such book for a fee of Kcs 1,000 (approximately US\$35 or one-third of the average monthly wage in Czechoslovakia at the time). Upon registering, each citizen was entitled to bid for shares of enterprises that allocated shares to the voucher scheme in the first wave. Each voucher book, formally worth 1,000 investment points is divided into ten 100point parts. Before the bidding process started (in the so-called zero round), individual participants could allocate the entirety or parts of their voucher books to one or several IPFs. The IPFs were required to provide basic information about themselves and their investment strategies. Individual investors also had access to background information about the firms that entered the voucher scheme (including their profitability, indebtedness, sales, employment, and the extent to which a fraction of shares was being acquired by a domestic or foreign firm).

The bidding for shares of enterprises was organized within several rounds. Before each round the authorities would announce for each company its share price, the number of available (remaining) shares and the extent of excess demand registered in the previous round. In the first round the price was set identically for all companies and it was adjusted individually for each enterprise thereafter.

At the end of each round, the Center for Voucher Privatization at the Federal Ministry of Finance processed the bids as follows:

a) If the demand for shares of a given company was equal or less than the supply of shares, all orders were met at the price set for that round. The authorities then reduced the share price for excess supply companies;

b) If demand exceeded supply by less than $25 \%$ and the presence by the IPFs was significant, the demand of individual investors was met and the IPFs were rationed proportionately to their bids. The presence of IPFs was deemed to be significant if their demand did not have to be reduced by more than $20 \%$. In this case all shares were sold at the going price and were hence no longer available for bids in the following round;

c) If demand exceeded supply and the conditions in b) above were not satisfied, no transaction took place (the points were returned to their owners) and the authorities raised the share price for the following round.

According to the announcement of the Price Commission, prices were set ac- 
cording to a complex algorithm, involving as many as 17 indicators. The algorithm was never revealed but econometric estimations of price-setting equations carried out by Svejnar and Singer (1993) and Hanousek and Lastovicka (1993) show that the price setting behavior of the authorities may be fit very precisely by a relatively simple estimating equation. The most important variables explaining the price setting behavior were the share price in the previous round and the excess of demand over supply of shares (both variables having positive coefficients) as well as the total supply of shares (entering the equation with a negative coefficient). Both studies also indicate that the estimated coefficients varied across rounds. It hence appears that the authorities used a relatively simple set of rules for setting prices and that the rules changed from round to round. Interestingly enough, the Svejnar and Singer (1993) study also shows that the coefficients of the price setting equations differed significantly between the Czech and Slovak republics.

The conduct and termination of the first wave of voucher privatization was left at the discretion of the Federal Ministry of Finance. The Ministry had the autonomy to decide on how to adjust prices, whether or not to take firms with significant excess demand out of the process and when to declare a final round. Since all unused points became void, the uncertainty induced by the Ministry exerted a significant pressure on investors and the IPFs to bid so as to place their points.

\section{The Timetable of Voucher Privatization}

The timetable of voucher privatization is summarized in Table 10. As can be seen from the table, after about half a year of preparation the actual bidding for shares took place in five rounds from 18 May to 22 December 1992. Hence, the entire process lasted slightly more than a year, with the bidding part taking seven months.

Until mid-May 1993, shares of Slovak enterprises were being transferred to new owners but the Czech government made the distribution of shares of Czech enterprises contingent on the resolution of a Czech-Slovak dispute over the division of property and clearing of debts. However, on 13 May the Czech government announced that it would proceed with the distribution of shares of Czech enterprises to both the Czech and Slovak citizens on 24 May 1993.

Privatization projects for the second wave (which has so far been taking place in the Czech Republic only) had to be approved by the end of October 1993. Between October and early December 1993, citizens could registered their voucher books and as of 15 December 1993 they could assign their vouchers to Investment Privatization Funds. Actual rounds of bidding were to start on 21 March 1994. As in the first round, the duration and number of rounds (as well as the termination of the process) is left at the discretion of the (Czech) Ministry of Finance. 
Table 10 - TIMETABLE OF THE FIRST AND SECOND WAVES OF VOUCHER PRIVATIZATION

\begin{tabular}{|c|c|c|c|}
\hline & Start & Bids until & End of period \\
\hline $\begin{array}{l}\text { Privatization projects approved } \\
\text { - first wave } \\
\text { - second wave }\end{array}$ & $\begin{array}{l}31 \text { April } 1992 \\
29 \text { October } 1993\end{array}$ & & \\
\hline $\begin{array}{l}\text { SOE for vouchers registered as JSC } \\
\text { - first wave } \\
\text { - second wave }\end{array}$ & $\begin{array}{l}11 \text { May } 1992 \\
1 \text { December } 1993\end{array}$ & & \\
\hline $\begin{array}{l}\text { Vouchers to be registered by citizens } \\
\text { - first wave } \\
\text { - second wave }\end{array}$ & $\begin{array}{l}1 \text { November } \\
1 \text { October }\end{array}$ & & $\begin{array}{l}28 \text { February } \\
8 \text { December }\end{array}$ \\
\hline $\begin{array}{l}\text { Investment privatization funds registered } \\
\text { - first wave } \\
\text { - second wave }\end{array}$ & $\begin{array}{l}17 \text { February } 1992 \\
15 \text { November } 1993\end{array}$ & & \\
\hline $\begin{array}{l}\text { List of IPFs published } \\
\text { - first wave } \\
\text { - second wave }\end{array}$ & $\begin{array}{l}28 \text { February } 1992 \\
\text { End of Novernber } \\
1993\end{array}$ & & \\
\hline $\begin{array}{l}\text { List of Supplied Enterprises published } \\
\text { - first wave } \\
\text { - second wave }\end{array}$ & $\begin{array}{l}18 \text { May } 1992 \\
\text { February } 1994\end{array}$ & & \\
\hline $\begin{array}{l}\text { First wave (1992) } \\
\text { - zero round } \\
\text { - first round } \\
\text { - second round } \\
\text { - third round } \\
\text { - fourth round } \\
\text { - fifth round }\end{array}$ & $\begin{array}{l}1 \text { March } \\
18 \text { May } \\
8 \text { July } \\
26 \text { August } \\
14 \text { October } \\
23 \text { November }\end{array}$ & $\begin{array}{l}26 \text { April } \\
8 \text { June } \\
28 \text { July } \\
\text { 15 September } \\
27 \text { October } \\
4 \text { December }\end{array}$ & $\begin{array}{l}12 \text { May } \\
30 \text { June } \\
18 \text { August } \\
6 \text { October } \\
17 \text { November } \\
22 \text { December }\end{array}$ \\
\hline $\begin{array}{l}\text { Shares passed to citizens and IPFs } \\
\text { Second wave (1993/4) - zero round } \\
\text { Second wave (1994) - first round }\end{array}$ & $\begin{array}{l}24 \text { May } 1993^{*} \\
15 \text { December } 1993 \\
1 \text { March } 1994\end{array}$ & & \\
\hline
\end{tabular}

* In the Slovak Republic, shares were issued on 29 March.

\subsection{Investment Privatization Funds (IPFs)}

The law on Conditions of Transferring State Property to Other Persons (no. 92/1991) permits the participation of IPFs in voucher privatization. Although the decree on the Issue and Use of Privatization Vouchers (no. 383/91) and its amendment (no. 62/1992) from early 1992 have established certain regulations for the operation of IPFs, a law regulating the IPFs (law no. 248/1992 'On Investment Corporations and Investment Funds') was passed only on 28 April 1992 - two months after the deadline for registering IPFs. Until then, the founding of IPFs was guided by the law on Joint Stock Companies (no. 104/1990), or, after 31 December 1991, by the newly introduced Commercial Code (no. 513/1991). Neither of these laws 
addresses in detail the issue of investment companies. The laws hence do not impose any restrictions or regulations on their conduct. The screening of funds participating in the first wave of voucher privatization was therefore done only by the Privatization Ministries of the Czech and Slovak Republics, which had to approve each IPF's eligibility for participation in voucher privatization.

The delay in passing the law on Investment Corporations had two negative effects on the first wave: the limited regulation and oversight of IPFs and the fact that the only permissible form of an IPF was a 'Legally Independent Joint Stock Company' - a form which entails costly management and accounting. The $1992 \mathrm{Law}$ on Investment Corporations and Investment Funds allowed this legal form as well as open or closed mutual funds with far easier and cheaper management. Both closed and open mutual funds have been widely used in the second wave, although the old form of IPFs still dominates.

To establish an IPF, its founder must be a corporation with equity of at least Kcs 1 million (about US\$33,000) per fund. In applying to the relevant Ministry of Privatization for approval, the founder must submit a proposal of the founder's plan, a draft contract between the founder and the IPF (which is established as a separate corporation) concerning the conditions of control of the fund, and a draft of the statutes of the IPF.

The founder's plan must contain:

- the management conditions of the fund;

- information on the number and qualification of the proposed administrators of the fund;

- information about the members of the board of directors and the supervisory board of the fund;

- the fund's investment policy towards sectoral specialization and risk taking; and

- certification that the equity of the fund would be Kcs 100,000 before the start of voucher privatization.

The contract between the founder and the fund has to contain conditions of reward of the founder for managing the fund. This reward cannot exceed $2 \%$ of the nominal value of the shares gained in voucher privatization within the course of privatization and $3 \%$ of the property of the fund one year after the privatization.

Finally, the most important regulatory clauses, introduced through amendments to the decree on the Issue of Vouchers, excluded top government officials from the boards of the IPFs and restricted each IPF from investing more than $10 \%$ of its points in a single company and obtaining more than $20 \%$ of shares of any company. IPFs established by a single founder were allowed to accumulate up to $40 \%$ of shares in a given company but this percentage was later reduced to $20 \%$. However, the clause proved ineffective since IPFs can (and do) merge. Finally, a clause of law no. 248/1992 forbids IPFs founded by financial institutions from purchasing shares of financial institutions. This clause was aimed at preventing excessive concentration of financial capital as shares of the largest commercial banks, insurance companies and saving and loans institutions were offered through the voucher scheme 
in the first wave (see Table 11).

Table 11 - MAJOR FINANCIAL INSTITUTIONS IN THE FIRST WAVE

\begin{tabular}{|c|c|c|c|c|c|}
\hline Institution* & $\begin{array}{c}\text { Book } \\
\text { Value }^{\wedge}\end{array}$ & $\begin{array}{c}\text { Vouchers } \\
\text { (\%) }\end{array}$ & $\begin{array}{c}\text { Other } \\
\text { Investors }\end{array}$ & $\begin{array}{l}\text { FNP } \\
(\%)\end{array}$ & $\begin{array}{l}\text { Restitution } \\
\text { Fund (\%) }\end{array}$ \\
\hline Commercial Bank & 4.56 & 53 & - & 44 & 3 \\
\hline Vseobec. Uverova Bank & 2.04 & 52 & - & 45 & 3 \\
\hline Czech Savings \& Loan Bank & 5.60 & 37 & $\begin{array}{l}\text { Free transfer to local } \\
\text { governments }(20 \%)\end{array}$ & 40 & 3 \\
\hline Investment Bank & 1.00 & 52 & - & 45 & 3 \\
\hline Czech Insurance Company & 1.64 & 15 & $\begin{array}{l}\text { S\&L Investment Fund } \\
\text { First Investment Fund } \\
\text { CS. Trade Bank (77\%) } \\
\text { Interbank } \\
\text { Employees }(5 \%)\end{array}$ & - & 3 \\
\hline
\end{tabular}

* the first two institutions are the largest Czech and largest Slovak commercial banks.

$\wedge$ billions Kcs

\subsection{The Voucher Scheme at Work}

\subsubsection{First wave}

On the supply side, a total of 1,491 enterprises offered some of their shares in the first wave of voucher privatization. Of these, 593 were Slovak and $988 \mathrm{Czech}$ firms (Table 6). There were significant differences between the privatization projects for voucher privatization in the two republics, as Slovak firms tended to rely more exclusively on voucher privatization than firms in the Czech republic. In particular, only $39.7 \%$ of the Czech firms entering voucher privatization used vouchers as an exclusive method, while in Slovakia $90.1 \%$ of projects did so. Many Czech projects combined the voucher method with sales to domestic or foreign investors or with creating a joint venture. ${ }^{30}$ Nevertheless, as can be seen from Table 12 , many Czech projects actually allocated a high proportion of shares to voucher privatization. ${ }^{31}$

Table 12 - SHARE OF VOUCHERS PROJECTS APPROVED BY THE CZECH MINISTRY OF PRIVATIZATION, 31 APRIL 1991

\begin{tabular}{lcccc}
\hline Share of Vouchers & $1-25$ & $26-50$ & $51-75$ & $76-100$ \\
\hline Number of Companies & 16 & 96 & 176 & 660 \\
\hline
\end{tabular}

Source: The Ministry of Privatization of the Czech Republic.

In some cases the Fund of National Property keeps part of the property. The reasons for this decision include the desire to preserve domestic majority ownership, influence the situation in important companies during negotiations with foreign or domestic investors (e.g., in major banking institutions), and ensure the realization of joint venture agreements (shares held by the Fund are transferred to the 
foreign partner once he fulfils agreed upon conditions). Table 11 provides an illustration of this principle in the financial sector. Of course, the shares in Funds' holding can also be sold, auctioned, offered at the stock market or sold through intermediaries.

On the demand side, the developments in the first wave were rather dramatic. Between November 1991 and early January 1992, only several hundred thousand persons registered their voucher books. Government estimates at the time indicated that around 2.5 million inhabitants would register before the deadline, with the book value of voucher property per voucher book thus amounting to $\operatorname{Kcs} 70,000$. The number of registered citizens actually reached 2.5 million in mid-January 1992, just as several private and bank-sponsored IPFs started an aggressive campaign to induce citizens to register voucher books and deposit them with the IPF. One of the private companies controlling several funds, Harvard Capital \& Consulting, focused on undecided individuals by offering each person registering his/her vouchers with a Harvard IPF the option to sell his/her IPF shares to Harvard for Kcs 10,035 (ten times the cost of registering vouchers) in one year. This strategy, copied by several other funds, ${ }^{32}$ induced 8,566 million citizens (approximately $75 \%$ of all eligible individuals) to register before the end of February 1992. While greatly popularizing the voucher method, the stampede naturally reduced the value of assets per participant. In fact, the book value of assets per voucher book fell to Kcs 35,000 .

In fact, 434 IPFs, of which 264 in the Czech and 170 in the Slovak Republic, were founded by various organizations and entered the zero round on 1 March 1992. The most successful in attracting vouchers were funds connected with large financial institutions. Overall, $72 \%$ of voucher points were placed with IPFs, leaving only $28 \%$ for direct bidding by individual voucher investors. The overwhelming registration of points with the IPFs probably reflects both the desire of the citizens to diversify risk and the perceived guarantee of the funds to pay a multiple of the cost of the voucher points.

As can be seen from Table 13, citizens of both republics tended to invest their points in their domestic IPFs, although Slovaks invested more in the Czech IPFs than vice versa. This tendency was seen even more clearly in the actual bidding for shares in the five rounds. Another significant feature - possibly a very important one for the future role of funds in the Czech and Slovak economies - is the tendency to place points into large, well known funds, instead of funds specializing in particular sectors or regions. Among the nine most successful IPFs, there was only one not connected with a major financial institution (Harvard Capital \& Consulting) and only one founded by a foreign bank (Credit, affiliated with a major Austrian bank). Thirteen of the largest IPF founders controlled over $56 \%$ of all points given to the funds and, as can be seen from Table 14, the degree of concentration was high by other criteria as well.

As mentioned earlier, the actual bidding for shares in the first wave of voucher privatization took place in five rounds. As can be seen from Table 15, a full $30 \%$ of shares allocated into voucher privatization were sold in the first round and $25.9 \%$ 
cleared the market in round 2 . By the time the fifth round was finished, about $92 \%$ of all shares were transacted. In terms of voucher points, the IPFs spent $99.7 \%$ of their voucher points, while individual investors placed $96.5 \%$ of their points. The participation of investors was also massive as over $88 \%$ of available points was placed in bids in every round.

Table 13 - THE ZERO ROUND ALLOCATION OF VOUCHER POINTS (million points)

\begin{tabular}{lccc}
\hline & Czech Republic & Slovak Republic & Total \\
\hline Obtained by citizens & 5980 & 2580 & 8560 \\
& & & 1820 \\
Given to IPFs & 4320 & 180 & 6130 \\
- Czech IPFs & 4290 & 1630 & 4470 \\
- Slovak IPFs & 30 & 1660 \\
\hline
\end{tabular}

Table 14 - STRUCTURE OF IPFs BY SIZE (millions of received points)

\begin{tabular}{lccccccc}
\hline & $<1$ & $1-5$ & $5-10$ & $10-50$ & $50-100$ & $>100$ \\
\hline Number of IPFs & 191 & 122 & 43 & 59 & 6 & 13 \\
\hline
\end{tabular}

The IPFs tended to use a larger percentage of their points and hence buy relatively more shares in earlier rounds than individual investors. This undoubtedly reflected in part the official pressure on the IPFs to participate massively in the scheme. It may have also reflected a strategy of the funds to obtain shares of specific companies almost at any cost. Since the average share price declined after the second round (Table 15), individual investors on average purchased cheaper shares than the IPFs.

As can be seen from Table 15, in any given round very few firms succeeded in selling all of their shares. Most of them flipped between states of significant excess demand and excess supply, with most trades taking place in the situation of excess supply. At the end of the fifth round, only about $20 \%$ of the firms cleared the market. The bidding scheme hence failed to reach complete convergence and in many respects was rather inelegant. Nevertheless, from a purely practical standpoint it was a success in that virtually all voucher points were exchanged for shares and only about $8 \%$ of shares remained unsold.

The authorities maintained considerable uncertainty about the price adjustment process and the timing of the termination of the voucher scheme. Occasionally (for example, between rounds 2 and 3 ) they overreacted in adjusting prices and caused low levels of transactions. On the whole, however, they demonstrated that a scheme of this kind is feasible.In an analysis of the determinants of demand for shares by the individual investors and IPFs, Svejnar and Singer (1993) find that the individual and institutional investors tended to behave quite rationally during the rounds of bidding. In the first round, when all share prices were set identically and the behaviour of other investors was unknown, the demand of the individuals as well as IPFs was guided primarily by background economic indicators of enterprise 
performance, such as profitability, indebtedness and size. As prices were adjusted between rounds, supply (availability) of shares shrank unevenly across firms and the extent of excess demand became evident, these time-varying variables supplanted the time-invariable background variables as the main determinants of individuals' and IPFs' demand (bids).

As we mentioned earlier, the price setting behaviour of the authorities could be very closely approximated by a simple equation in excess demand, previous price and supply of shares. These findings are consistent with institutional observations that the authorities in practice disregarded their elaborate models and used an ad hoc price adjustment scheme between the rounds.

After concluding the last round of the first wave of voucher privatization on 22 December 1992, the government decided to delay the confirmation of ownership of shares ${ }^{33}$ until 29 March 1993 - three months after the results of the last round were processed and published. This decision was widely criticized as being harmful to the privatized enterprises as it significantly delayed the ability of shareholders to call their first general meetings. The government thus prolonged the period of virtually nonexistent supervision of the old, state-appointed management. As we mentioned earlier, things went even worse in the Czech Republic where a dispute with the Slovak Republic delayed the confirmation of share ownership until 24 May 1993. The precarious period between the submitting of projects (which often caused struggle inside the management) to the date when new owners would assume control over the property thus frequently exceeded two years. This aspect of voucher privatization, caused by the need to prepare large amounts of property at once and then organize a complex and cumbersome matching procedure, is one of the major disadvantages of this method.

\subsubsection{The Second Wave}

As of the writing of this paper, the second wave has been organized in the Czech Republic only. In terms of the number of companies and value of assets, the second wave will be smaller than the first one. Whereas in the first wave shares representing Kcs 212.5 billion of book value of 988 Czech enterprises were transacted (the remaining Kcs 86.9 billion of book value reflected Slovak firms), the second wave offers shares of 780 to 800 firms representing only 148 to 150 billion Czech koruna $(\mathrm{Kc})$ in book value. Of this amount, $\mathrm{Kc} 21.1$ billion worth of shares are shares of 100 firms that were offered but not sold in the first wave.

On the other hand, the participation rate of Czech citizens is higher than in the first wave: in the first one, 5.83 million citizens registered their vouchers, while 6.07 million ( $85 \%$ of all eligible citizens) registered their voucher books for the second wave. Participants in the second wave of voucher privatization may choose from 353 investment and mutual funds, with investment funds numbering 195 and mutual funds 158 . Only 37 mutual funds are open funds. Of the 264 investment funds which took part in the first wave of voucher privatization, 218 have survived until now (the rest have mostly merged with larger funds) and 134 entered the second wave. 
Table 15 - THE FIVE ROUNDS OF THE FIRST WAVE OF VOUCHER PRIVATIZATION

\begin{tabular}{|c|c|c|c|}
\hline & $\begin{array}{c}\text { Czech } \\
\text { Republic }\end{array}$ & $\begin{array}{c}\text { Slovak } \\
\text { Republic }\end{array}$ & Total \\
\hline \multicolumn{4}{|c|}{ 1. \% of Voucher Scheme Shares sold in Wave 1} \\
\hline - Round 1 & 21 & 8.8 & 30.0 \\
\hline - Round 2 & 18.1 & 7.9 & 25.9 \\
\hline - Round 3 & 7.0 & 3.9 & 10.8 \\
\hline - Round 4 & 8.5 & 3.9 & 12.4 \\
\hline - Round 5 & 8.1 & 5.5 & 13.7 \\
\hline \multicolumn{4}{|c|}{ 2. \% of Unallocated Voucher Points of Individuais after } \\
\hline - Round 1 & 77.2 & 65.4 & 73.0 \\
\hline - Round 2 & 38.9 & 34.1 & 37.5 \\
\hline - Round 3 & 24.7 & 21.8 & 23.75 \\
\hline - Round 4 & 13.6 & 14.1 & 13.8 \\
\hline - Round 5 & n.a. & n.a. & 3.5 \\
\hline \multicolumn{4}{|c|}{ 3. \% of Unallocated Voucher Points of IPFs after } \\
\hline - Round 1 & 61.3 & 64.0 & 61.0 \\
\hline - Round 2 & 18.3 & 25.3 & 20.2 \\
\hline - Round 3 & 7.4 & 13.3 & 9.0 \\
\hline - Round 4 & 3.8 & 7.2 & 4.7 \\
\hline - Round 5 & n.a. & n.a. & 0.3 \\
\hline \multicolumn{4}{|c|}{ 4. \% of Available Points Used in Bidding } \\
\hline - Round 1 & 91.7 & 92.6 & 92.0 \\
\hline - Round 2 & 91.0 & 79.6 & 88.0 \\
\hline - Round 3 & 93.1 & 96.2 & 93.0 \\
\hline - Round 4 & 87.9 & 89.7 & 88.5 \\
\hline - Round 5 & 92.1 & 87.5 & 90.3 \\
\hline \multicolumn{4}{|c|}{ 5. Average Share Price in Points } \\
\hline - Round 1 & 33.33 & 33.33 & 33.33 \\
\hline - Round 2 & $54.00^{*}$ & $21.00^{\text {* }}$ & 43.86 \\
\hline - Round 3 & 39.22 & 17.89 & 31.45 \\
\hline - Round 4 & 15.08 & 11.53 & 13.76 \\
\hline - Round 5 & 15.13 & 9.12 & 12.69 \\
\hline \multicolumn{4}{|c|}{ 6. No. of Firms that Sold all Shares } \\
\hline - Round 1 & 30 & 18 & 48 \\
\hline - Round 2 & 55 & 17 & 72 \\
\hline - Round 3 & 24 & 27 & 51 \\
\hline - Round 4 & 57 & 22 & 79 \\
\hline - Round 5 & 26 & 14 & 40 \\
\hline \multicolumn{4}{|c|}{ 7. No. of Firms in Excess Demand } \\
\hline - Round 1 & 350 & 119 & 469 \\
\hline - Round 2 & 342 & 171 & 513 \\
\hline - Round 3 & 362 & 145 & 508 \\
\hline - Round 4 & 239 & 130 & 369 \\
\hline - Round 5 & 99 & 58 & 157 \\
\hline \multicolumn{4}{|c|}{ 8. No. of Firms in Excess Supply } \\
\hline - Round 1 & 638 & 384 & 1022 \\
\hline - Round 2 & 615 & 314 & 929 \\
\hline - Round 3 & 515 & 295 & 810 \\
\hline - Round 4 & 580 & 288 & 868 \\
\hline - Round 5 & 719 & 360 & 1079 \\
\hline
\end{tabular}

* Government estimate.

Source: Czechoslovak Federal Ministry of Finance as cited in J. Svejnar and M. Singer (1993). 


\subsubsection{Preliminary Results}

Since June 1993, shares distributed through voucher privatization are traded at the Prague Stock Exchange (Czech companies) and Bratislava Stock exchange (Slovak companies). In both republics, shares are also traded at the automated RMSystem, based on the infrastructure of registration places from voucher privatization. Both the stock exchange and RM-Systems started with a structure of prices reached in bidding procedure of voucher privatization. At the start the price level was set quite high so that both the RM-System and Stock Exchange were in a situation of excess supply. In Prague, prices kept falling until the middle of September but have risen significantly since then. At end of December 1993 the index of the Prague Stock Exchange exceeded its minimum point by more than $100 \%$ and the index of the RM-System slightly less than that. The volumes of trading are also quite significant. Between 22 June and 16 December, papers for $\mathrm{Kc} 8,818$ million changed hands at the Prague Stock Exchange and another Kc 2,904 million at the RM-System. ${ }^{34}$ Whereas the Prague Stock Exchange trades twice a week, the RMSystem has three week long rounds; the Stock Exchange is used by institutional investors, while the RM-System serves as a retail complement in the system. Prices differ across those two markets in some cases by $100 \%$ margins, but due to long waiting periods in the RM-System, arbitrage is costly. The Slovak market has so far exhibited lower prices and thinner volumes: total volume for 1993 has reached only 44 million Slovak koruna $(\mathrm{Ks})$.

The most important consequence of privatization, namely the change in corporate governance and management behavior is most difficult to observe. The small influence of small individual shareholders on management is not surprising. On the other hand, some of the largest funds have generally invested into very limited portfolios and are exercising their property rights rather actively. However, conclusions about the effects of voucher privatization on management and efficiency of former state owned enterprises may be drawn only on the basis of systematic studies of economic performance which have not yet been carried out.

\subsubsection{Voucher Privatization: The Next Step}

The bidding phase of the second wave will start in March 1994. Since the participants of this wave may have learned in the first wave, their behaviour and hence the dynamics of the second wave may be quite different. The following factors may also play an important part in the second wave:

- IPFs generally honored their promises but with delays and, in some cases, they paid smaller amounts than promised; 35

- funds are promising less in second wave; after poor start of zero round, several funds started to pay cash in advance, which attracted a lot of people. In contrast to 10,000 and more promised in the first wave, Harvard funds pay now 3,000. The highest offer is 7,000 Kc;

- prices of the shares at both Czech stockmarkets are relatively high. The shares gained by a well-invested voucher in the first wave can be sold for as much as 
$200,000 \mathrm{Kc}$;

- shares of funds that have been traded at the stock market show lower prices and weaker trading. Yet since their rise in December, shares of companies are doing better.

These factors generally contribute to the lowering of the share of funds. Unless the higher total participation of citizens in wave two reverses this trend, the second wave may display different characteristics from the first one. According to Singer and Svejnar's (1993) estimations, funds and individual bidders showed different demand strategies, with individuals having higher price elasticity and the funds tending to bid for firms with a high number of shares offered in each round. Funds were hence taking into account the strategic aspect that their sizable investment decisions could bring about excess demand in situations of limited share supply.

\subsection{Large Scale Privatization: Achievements and Problems}

The size of the Czechoslovak large scale privatization program is unprecedented in the world. As a result, it is naturally impossible to undertake a comparative evaluation of the process and its outcome. Nevertheless, it is indisputable that the Czechs and Slovaks have proved that a large scale transfer of ownership program of this kind is feasible and can be carried out in a relatively short period of time. The main problems associated with the Czechoslovak scheme appear to have been the following:

The legislative framework for large scale privatization, especially for the voucher component, was too vague. Most of the laws spelled out general principles, relegating details to government decrees and ad hoc administrative decisions. This gave the governments great discretionary power which lent itself to abuse. As an example, the timing and method of concluding the first wave of voucher privatization was determined fully by a handful of officials. Investors were told that the voucher scheme could be concluded at any time with an ex post announcement from this group, with their leftover voucher points becoming worthless.

Voucher privatization also turned out to be difficult to organize. One of the important advantages, expected by the Czechoslovak authorities when the method was accepted, was that the use of this method could turn the difficult decision process of 'whom to sell to' into an easier approval process of 'whether to privatize this enterprise or not'. However, as soon as the method started to compete and was being combined with other, standard methods, this expected advantage disappeared. The consequence was a difficult process that permitted corruption to appear.

On the other hand, one may argue that using the voucher method as a single privatization tool would have been too risky and that the complications brought about by the use of a combination of methods are more than outweighed by the benefits of diversification.

An important positive result is that in spite of predictions of many economists, no massive sell out of shares has so far occurred. Stock prices have shown considerable fluctuations as might be expected with new issues, but there has so far been no major sell off of shares. 


\section{The Role of Foreign Investment in Privatization}

Foreign capital plays a part in the emerging private sector of the Czech and Slovak republics. According to the Czech National Bank, the total 1992 inflow of foreign investment was about US\$1.1 billion, over $90 \%$ of which went to the Czech republic and over 9\% to Slovakia. In first nine months of 1993, another US\$455 million came to the Czech republic as direct foreign investment. Since the beginning of the transition process in 1990, foreign investment has totalled US $\$ 2$ billion, to the Czech economy only. The inflow of western capital has thus been relatively modest so far and most of it has located in the Czech republic.

There has also been an interesting dynamics in the national composition of foreign capital. Whereas for the entire 1990-92 period German capital ranks as the most important source of foreign investment (38.5\% of the total), in 1992 the most active investors were the Americans (27.2\%) and French (20.7\%), leaving the Germans in the third place with $16.9 \%$ of total foreign investment. Czechoslovakia has thus enjoyed a significant investment inflow from its economically advanced neighbour, but increasingly it has also benefited from a diversified foreign investment base.

The most frequent avenues through which foreign capital has been entering the Czech and Slovak economies are:

- the formation of joint ventures with existing enterprises;

- the establishment of new firms or affiliations;

- the purchase of existing firms within the privatization process.

The process of establishing new firms and joint ventures has been gradually deregulated so that at present no formal government approval is necessary. Several thousand fully or partly foreign-owned firms are now registered, although most of them are 'empty shells' that have never started business activities.

Foreign participation in the privatization process has been restricted within each privatization program. Foreign citizens are not entitled to claim restitution demands and their bidding is subjected to special rules in the small privatization. Within large scale privatization foreign bidders can generally take part in any form of privatization with the exception of methods leading to free distribution of property. This means prevailingly free transfers and direct involvement in voucher privatization. On the other hand, foreign companies could establish investment privatization funds and some of them, like Austrian Creditanstalt, became one of the most successful ones.

The purchase of state-owned firms and creation of joint ventures with firms going through the privatization process has been legally more difficult. In our discussion of small and large scale privatization, we have outlined the nature of these difficulties. Despite the fact that some clandestine purchases through Czechoslovak citizens may have taken place, the exclusion of foreign capital from the first wave of auctions in small scale privatization makes foreign investment in these units likely to be negligible. The centralized nature of large scale privatization generates better information. As can be seen from Table 16, the total number of 102 approved foreign projects does not look impressive in comparison with the thousands of firms 
that are being privatized. However, many of the foreign projects are of key importance.

For instance, in 1991 Volkswagen acquired $31 \%$ of shares in the Czech car maker, Skoda Mlada Boleslav, for over US $\$ 300$ million. Skoda was responsible for $5 \%$ of the country's exports and so far the deal has been the largest one in the Czech and Slovak republics. The commitments of Volkswagen's future investment in the venture exceed US\$1 billion over the following five years, although the cancellation by Volkswagen of a major loan for Skoda in 1993 has cast doubt on the seriousness of this commitment.

Two other widely publicized cases were the sales of the entire detergent factory Rakona to Procter \& Gamble and of Maj, one of largest department stores in Prague, to K-Mart. In both cases the sale price was around US $\$ 10$ million with commitments for additional investment amounting to a multiple of this price.

Foreign investors also entered into enterprises included in voucher privatization. In 37 out of the 988 Czech enterprises and 8 out of the 503 Slovak enterprises involved in the first wave of voucher privatization, the voucher method was complemented by a direct sale of some proportion of shares to a foreign investor. In many other cases, foreign investors entered later by directly purchasing shares of companies from the Funds of National Property or from intermediaries through whom the Funds also sell shares. Table 17 illustrates three cases where the voucher method was complemented with a significant minority or majority foreign ownership.

\section{Conclusions}

The Czech and Slovak privatization program has provided an answer to one of the most hotly disputed practical propositions of this decade, namely whether it is possible to privatize a large part of a virtually completely state-owned economy within a short time span. After forty years of virtually no experience with private ownership, a new and inexperienced government assembled and rapidly implemented three complementary privatization programs that transferred state ownership to individuals, groups and the population at large.

One of the main lessons of our examination of the Czech and Slovak experience is that the determination of a strong government to privatize was an essential element of the success. Indeed, the design of the privatization programs had arguably many flaws and the Czechs and Slovaks encountered numerous difficulties (many of their own doing) in implementing the relatively complex schemes of transferring ownership. Yet, the government's perseverance and problem-solving approach created an atmosphere of credibility and trust that generated and maintained the necessary public support for the program.

The main challenge facing the Czech and Slovak governments is to complete the program of large scale privatization and provide an environment conducive to efficiency gains that should result from the new system of ownership. The double digit and rising unemployment rate in Slovakia, as well as the political-economic orientation of the Slovak government, has generated a certain opposition to further 
mass privatization in that country. At present, the course appears steady in the Czech republic and somewhat uncertain in Slovakia.

The second part of the challenge concerns the efficiency gains that are expected to stem from the privatization program. The introduction of a multitude of flexible and responsive small firms in the restitution and small scale privatization programs has produced immediate and visible welfare gains. The short term efficiency outcome in large scale privatization is less certain, however, as the delay in transferring property rights and the dispersed nature of the new ownership may not rapidly generate the desired control over (mostly state appointed) management. The ability to convert the massive transfer of ownership into rapid and sustained efficiency gains in the economy is the next challenge in the Czech and Slovak transition process.

\section{This paper was received on 15 January 1994.}

\section{Notes}

1 After the partition of Czechoslovakia into independent Czech and Slovak republics on 1 January 1993, it has been much more difficult to obtain information on the progress of privatization in Slovakia than in the Czech republic. As a result, for 1993 our discussion of the Slovak case is less detailed than that of the Czech case.

2 The Federal Fund was created by law $92 / 1991$ on 26 February 1991, and its operation legally started on 1 April 1991. The Czech Fund was established by law no. 171/191 on 23 April 1991 and its operation became effective on 24 May 1991. The Slovak Fund was established by law no. 253/1991 on 24 May 1991, and became legally effective on 28 June 1991.

3 See Svejnar J. and M. Singer (1993) for an analysis of this price setting behaviour.

4 These fears had, at least in part, materialized. For example, in Prague's District 4, $70 \%$ of all contracts returning buildings from the state to the previous owners or their heirs were not accepted by the notary because of legal problems in these signed contracts. Of approximately 1,000 claims, only 150 resulted in the return of the property as of 30 September 1991 [Respekt, 21-27 October 1991]. Yet, according to the Czech Ministry of Privatization, restitutions have been a much faster vehicle of privatization than the auction method used in small privatization.

5 Many professional economists have for instance opposed restitutions. David Begg (1991) spoke for many when he declared that he, "see(s) no moral case for restitution. Previous owners did lose out...But others lost out too'. Before the law on restitutions was passed through the federal Parliament, two dozen Czech and Slovak economists (among them two federal, three Czech and two Slovak ministers) questioned the technical feasibility of mass restitutions. In the end the law passed with the support of all parliamentary parties except the communists.

${ }^{6}$ One of the most controversial issues is the exclusion of former Czechoslovak citizens, who lost their citizenship as a result of communist, now unconstitutional, laws. Although there have been many initiatives to allow restitutions for those former Czechoslovak citizens, who lost their citizenship under communism, so far these initiatives have not been successful. The initiatives have the support of conservative and liberal political parties.

7 The confiscation of personal property was a standard legal punishment in cases such as an 'illegal leaving the republic'. Although significant politically, the amount of property returned under this law is relatively small.

${ }^{8}$ In contrast, historical records are very good. Historical registration of deeds started in the 13 th century and the modern form of registration was principally unchanged since the mid-1700s. 
${ }^{9}$ See for example, Gacs J., Karimov I.A. and H. Schneider (1993) for an overview and comparison of small scale privatization programs in Central and Eastern Europe. For a broader comparison, see e.g., Voszka É. (1993).

10 The survey was carried out in January 1990 by AISA, the Association for Independent Social Analysis, Prague. The results were based on questionnaires filled out by 2,370 respondents.

11 Czechoslovak Economic Digest 2/1991 (English translation). The competencies of the republican governments in small privatization were articulated by laws no. $500 / 1990$ in the Czech republic and no. $427 / 1990$ in the Slovak republic.

12 Since October 1991 the two year period has been extended to five years for newly auctioned business units. Previous transactions may have the time of the lease reconsidered in the sense of this legal change, but only with approval of present owner of the building and/or land.

13 Therefore, refugees from communist persecution who returned to Czechoslovakia are eligible under this law. Those who would not become permanent residents in Czechoslovakia are not.

14 The Committees have been established and their jurisdiction is defined by republican laws no. 20/1990 of the Czech Parliament and no. 20/1990 of the Slovak Parliament.

15 The law limits the auctioning of property which was legally leased, provided the contract was completed before 1 October 1990 . In such cases the lessor can buy the property without auction. In practice, many contracts were signed later and predated. The privatization committees tend not to respect the ban of auction when they do have a suspicion (but not a proof) that the lease was falsely dated. The Ministry of Privatization cannot ignore the law, however, which has in turn caused significant tensions between the Ministries and committees.

16 This condition has been exploited by some employees of businesses that were scheduled for privatization in order to delay privatization. By bidding the highest price without an intention to buy, they effectively delayed privatization by 4 or even more months. The penalty for not buying was the forfeiting of the security (escrow) deposit, i.e., 10\% of the starting price. Since October 1991 the possible penalty has been increased to one-third of the actually reached price, which often exceeds the starting price by a factor of 5 or even 10 .

17 See for example Dyba K. and J. Svejnar (1993).

18 Borensztein E. and M. Kumar (1991) in their classification of privatization proposals mention only one proposal that does not fall into this category. This reflects to a large extent the orientation of the papers and proposals published in the West.

19 This form of privatization has been the dominant one in Germany (together with restitutions), Hungary (together with spontaneous privatization) and, until recently, Poland. The German reliance on standard methods follows from significant domestic capital base, entrepreneurial class and administrative might. Hungary, on the other hand, has been remarkable in its tolerance of spontaneous privatization and willingness to proceed gradually. Poland used a piecemeal approach to privatization while formulating its approach to large scale privatization. Recently, the Polish Parliament approved mass free distribution of property.

20 A summary of arguments presented in this internal document may be found in Komarek V. et. al. (1990).

21 Attitudes towards spontaneous privatization have differed significantly across countries: in Poland and Czechoslovakia this form of privatization has tended not to be tolerated by mainstream politicians (for the Polish case, see Da $\$$ browski M., 1991), whereas in Hungary it was at first by and large tolerated [see Kiss K., 1991] and Hungarian Economy, no. 2, 1991. However, as Dervis K. and T. Condon (1993) show, even in Hungary popular discontent has limited the reliance on this method since 1992.

22 See 'Iniciativni material ke koncepci deetatizace a privatizace', signed by the Union of Industry of the CR and SR and by the Union of State-Owned Enterprises and Joint Stock Companies and dated 4 July 1990.

${ }^{3}$ Published in Tydenik Hospodarskych novin, (1991), no. 12. 
24 The 'Lists of Enterprises' were published in Tydenik Hospodarskych novin, (1991), nos. $31,32,37,39$ and 40 .

25 Until 1 January 1993, federal property was referred for a final decision to the Federal Ministry of Finance.

26 The Ministry of Privatization of the Czech Republic issued a prototype of a privatization project [published in Tydenik Hospodarskych novin, (1991), no. 29], specifying the content and form of the project. A similar document was issued in Slovakia [Tydenik Hospodarskych novin, (1991), no. 38].

27 In the Czech Republic, for instance, a Regulation of Prices of Real Assets was issued by the Ministry of Finance of the Czech Republic on 5 September 1991 Ipublished in Hospodarske noviny, 13 September 1991]. This regulation increased official prices to a multiple of their former level.

28 In the first (1992) wave, federal property was transferred into the Federal Fund for National Property.

29 Among the most prominent scandals was the purchase of a wholesale book distributorship by the then vice premier of the federal government. The purchase was carried out for a nominal price but the distributorship included real estate in downtown Prague with an estimated market value of hundreds of millions Kcs.

30 Federally owned property was also privatized mostly in combination with at least two other methods.

31 Of the 948 projects reported in Table 12, 943 entered the first wave and 5 were approved at the end of 1992 for the second wave of voucher privatization.

32 The Czech Savings and Loans Bank for instance offered immediate credit of Kcs 10,000 to voucher holders who placed their points with its IPF.

33 In each company the shareholders decide whether shares will be issued physically or allocated and traded in a computerized system.

${ }_{35}$ Prague Stock Exchange was closed on 16 December; trading resumed on 6 January.

35 The famous Harvard funds, promising voucher holders Kcs 10,350 within a year tried to delay payments through a variety of legal manoeuvres. Just before voucher holders could opt for IPFs for the second wave, Harvard started to pay out the promised sum in an attempt to improve its chances. Surprisingly enough, a small fund which promised to pay Kes 31,050 for each voucher book has been buying out its shares at the promised price.

\section{References}

Begg D. (1991), 'Economic Reform in Czechoslovakia: Should We Believe in Santa Klaus', Economic Policy, no. 13.

Borensztein E. and M. Kuman (1991), 'Proposals for Privatization in Eastern Europe', IMF Staff Papers, vol. 38, no. 2.

Blanchard O., Dornbusch R., Krugman P., Layard R. and L. Summers (1991), Reform in Eastern Europe, Cambridge, Mass., MIT Press.

Da\$browski M. (1991), 'Privatization in Poland', Communist Economies and Economic Transformation, vol. 3 , no. 3 .

Dervis K. and T. Condon (1993), 'Hungary: An Emerging Gradualist Success Story?', paper presented at the 1992 NBER Conference on Transition in Eastern Europe, forthcoming in Blanchard O., Froot K. and J. Sachs (eds.) The Transition in Eastern Europe, Chicago, University of Chicago Press.

Dyba K. and J. Svejnar (1993), 'Stabilization and Transition in Czechoslovakia', paper presented at the 1992 NBER Conference on Transition in Eastern Europe, forthcoming in Blanchard O., Froot K. and J. Sachs (eds.) The Transition in Eastern Europe, Chicago, University of Chicago Press.

Frydman R., Rapaczynski A. and J.S. Earle (1993), The Privatization Process in Central Europe, Budapest-London-New York, Central European University Press.

Gacs J., Karimov I.A. and H. Schneider (1993), 'Small-scale Privatization in Eastern Europe and Russia: A Historical and Comparative Perspective', Communist Economies and 
Economic Transformation, vol. 5 no. 1. Paper.

Genberg H. (1991), 'On the Sequencing of Reforms in Eastern Europe', IMF Working

Hanousek J. and R. Lastovicka (1993), 'The First Fully Recorded Realization of a Closed Economy: A Methodology and Estimation using Czech Privatization Data', CERGEEI Discussion Paper, Prague.

Hungarian Chamber of Commerce (1991), Investor's Guide to Hungary 1991.

Kiss K. (1991), 'Privatization in Hungary', Communist Economies and Economic Transformations, vol. 3 , no. 3 .

Klvacova E. (1993), 'Velka privatizace mezi dvema vlnami', Ekonom, no. 5.

Komarek V. (1990), Prognoza a program, Prague, Academia Publishing House.

Lipton D. and J. Sachs (1990), Privatization in Eastern Europe: The Case of Poland, Brookings Papers on Economic Activity, no. 2.

Mladek J. (1993), 'Small Privatization in the Czech Republic: The Hey Day Is Over', Privatization Newsletter of Czechoslovakia, no. 13, January.

Siebert H. (1991), 'German Unification: The Economics of Transition', Economic Policy, no. 13, October.

Sik O. (ed.) (1990), Socialism Today, London: Macmillan.

Svejnar J. (1989), 'A Framework for the Economic Transformation of Czechoslovakia', PlanEcon Report, vol. V, no. 52.

Svejnar J. and M. Singer (1993), 'Using Vouchers to Privatize an Economy: The Czech and Slovak Case', CERGE Working paper, no. 36, Charles University, Prague, (forthcoming in Economics of Transition, 1994).

Vanek J. (1990), 'Beware of the Yeast of the Pharisees', Economic Analysis and Worker's Management, vol. 24, no. 1.

Vozska É. (1993), 'Privatization in Central East Europe: Can It Be Designed?', paper presented at the conference Institutional Design and Democratization in a Context of Economic Crisis, University of California at San Diego, May, 